\title{
The Right to Participate in the European Elections and the Vertical Division of Competences in the European Union
}

\author{
Sébastien Platon*
}

\section{Introduction}

The present book is, in part, dedicated to the federal division of competences in citizenship matters and the impact of EU Citizenship rights on the vertical division of powers in the EU. I would like to address here, more particularly, the right to participate in European elections and how the recent case-law on the subject may impact the distribution of competences between the European Union and the Member States.

As F. Fabbrini notes, "The concept of citizenship has been, since its modern reinvention, connected to the idea of political rights". ${ }^{1}$ This also applies to the European Union. EU citizenship is far from being a complete transnational status allowing each EU citizen to participate in all the national, regional and local elections in the country where they reside, and therefore "stands in sharp contrast to the situation in the United States, where the Citizenship Clause of the Fourteenth Amendment grants U.S. citizens the citizenship of the state in which they reside". 2 However, when EU citizenship was officially ${ }^{3}$ created in 1992, it came, for the first time, with an incipient status activus.

* Professor of Public Law, University of Bordeaux. The present chapter has been last updated

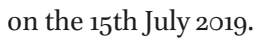

1 Fabbrini, F. (2017). The Political Side of EU Citizenship in the Context of EU Federalism. In: Kochenov, D., ed. (2017). EU Citizenship and Federalism. The Role of Rights. Cambridge: Cambridge University Press, p. 271.

2 Shaw, J. (2007). E.U. Citizenship and Political Rights in an Evolving European Union. Fordham Law Review 75 (5), pp. 2549-2578, 2549.

3 Several authors argue that citizenship already existed in substance, if not in texts, before the Maastricht Treaty. See for example Olsen, E. (2008). The origins of European citizenship in the first two decades of European integration. Journal of European Public Policy 15 (1), pp. 4057, 42; and Closa, C. (1992). The concept of Union citizenship in the Treaty on European Union. Common Market Law Review 29 (6), pp. 1137-1169. 
The right to vote and to run for the European elections predates de facto the creation of Union Citizenship with the Maastricht Treaty in 1992, since the Members of EU European Parliament have been elected by direct universal suffrage since $1976 .{ }^{4}$ However, the 1976 Act does not use the language of rights ("Elections shall be by direct universal suffrage and shall be free and secret"). By contrast, Art. $20(2)$ and 22 of the Treaty on the Functioning of the European Union (TFEU) provide that citizens of the EU enjoy, among others, the right to vote and to stand as candidates in elections of the European Parliament and in municipal elections in their Member State of residence, under the same conditions as nationals of that State. Therefore, the Maastricht Treaty constitutionalised the political rights of EU Citizens, which as such was a novelty. In any case, the right for EU Citizens to participate in the municipal elections of the Member State where they reside was undeniably something new in 1992. These new rights therefore constitute major improvements for the rights of Union citizens. ${ }^{5}$

In 2009, when the Charter of fundamental rights of the European Union came into force, these two Citizenship political rights became fundamental rights, enshrined in Art. 39 and 40. There is however a difference between the right to participate in municipal elections and the right to participate in European elections. Interestingly enough, the Court found that Art. 39 of the Charter not only contains a right to national treatment as regards European elections (just like Art. 40 contains a right to national treatment as regards municipal elections) but also an enforceable right to participate in European elections (II). Furthermore, this right has a broad scope of application vis-à-vis Member States, since it is applicable to national electoral legislation, including in purely internal situations (III). All this combined has the potential of blurring the distribution of powers between the European Union and the Member States in the field of election law (IV). Having explored these issues, I will then briefly offer a conclusion $(\mathrm{v})$.

\section{An Enforceable Right to Participate in European Elections}

Art. 39 Charter contains not only, in its first paragraph, the right of EU citizens to vote and to stand as a candidate in elections of the European Parliament in

41976 Act concerning the election of the representatives of the Assembly by direct universal suffrage, annexed to the Decision $76 / 787 /$ ECSC, EEC, Euratom of the representatives of the Member States meeting in the council relating to the Act concerning the election of the representatives of the Assembly by direct universal suffrage.

5 See Shaw, J. (2007). The Transformation of Citizenship in the European Union. Cambridge: Cambridge University Press. 
the Member State in which he or she resides, under the same conditions as nationals of that State - which is also enshrined in Art. 2O(2), b) and Art. 22(2) TFEU - but also, in its second paragraph, the more general principle according to which members of the European Parliament shall be elected by direct universal suffrage in a free and secret ballot, which mirrors Art. 14(3) TEU and Art. 1(3) of the 1976 Act concerning the election of the members of the European Parliament by direct universal suffrage.

The first paragraph is a "simple" right to national treatment. This is notably apparent from the wording of Art. 20(2), b) and Art. 22(2) TFEU and Art. 39(1) of the EU Charter which all state that every citizen of the Union has the right to vote and to stand as a candidate in elections of the European Parliament in the Member State in which he or she resides, "under the same conditions as nationals of that State". This interpretation is confirmed by the case-law of the Court, which said in Eman and Sevigner ${ }^{6}$ and Spain v. UK ${ }^{7}$ that Art. 19(2) of the Treaty on the European Communities (EC), now Art. 22(2) TFEU, was confined to applying the principle of non-discrimination on grounds of nationality to the right to vote and stand for European elections. In this respect, it is similar to the right to participate in municipal elections, enshrined in Art. 2O(2), b) and 22(1) TFEU and Art. 40 Charter.

The national treatment aspect of the political rights of EU citizens is consistent with the concept of citizenship and strongly connected with the requirement of equality between citizens. ${ }^{8}$ It has a strong normative potential to justify the abolition of all the remaining discriminations, limitations and inconsistencies affecting the political rights of EU citizens residing in other Member States. ${ }^{9}$ However, it only means that EU citizens can be treated as badly as the nationals of their State of residence as regards the European elections. It does not grant EU citizens, including nationals, an active right to participate in these elections, nor does it guarantee any minimum standard of treatment.

Despite the major breakthrough that was the decision to elect members of the European parliament at universal suffrage in terms of democracy and

6 Court of Justice, judgment of 12 September 2006, case C-300/04, Eman and Sevigner, para. 53 .

7 Court of Justice, judgment of 12 September 2006, case C-145/o4, Spain v. United Kingdom, para. 66.

8 See for example Lardy, H. (1996). The Political Rights of Union Citizenship. European Public Law 2, pp. 611-633, 622.

9 Fabbrini, F. (2017). The Political Side of EU Citizenship in the Context of EU Federalism, op. cit., 283 . 
citizenship, EU legal texts are, surprisingly, rather limited as regards both the existence of a proper individual right of EU citizens to participate in the European elections and the standards applicable thereto. All they say is that the members of the European Parliament shall be elected by direct universal suffrage (since 1976) ${ }^{10}$ and that the elections shall be "free and secret" (since 2002)..$^{11}$ These conditions are now also part of EU primary Law, in Art. 14(3) TFEU and Art. 39(2) of the Charter, which both provide that the members of the European Parliament shall be elected by direct universal suffrage in a free and secret ballot.

It is clear that these provisions create a legal obligation, for member States, to organise European elections under the prescribed conditions. However, before the Delvigne ruling in $2015,{ }^{12}$ it was not clear whether such vague provisions could be seen as granting a real, enforceable right to individuals. In 2006, the Court of Justice still considered, in Eman and Sevigner, that the provisions of (then) Part Two of the Treaty on the European Communities relating to citizenship of the EU did not confer on citizens of the EU an unconditional right to vote and to stand as a candidate in elections of the European Parliament. ${ }^{13}$ It is true that the circumstances of this case were specific, since it was about the right to participate in European elections in the Dutch island of Aruba. Aruba is one the overseas countries and territories ${ }^{14}$ which, according to Art. 198 et seq. TFEU are not territorially part of the European Union but are associated with it. Therefore, finding the existence of a right to participate in European elections would not have been very useful for this case since it could not have been assumed that this right was applicable in Aruba. However, the statement of the Court regarding the absence, in general, of an individual right to participate in European elections under EU law contrasts with the opinion of Advocate-General Tizzano in this case and in Spain v. UK. In his opinion, AG Tizzano clearly stated that he believed that EU citizens did have a right to vote in European elections under EU Law. ${ }^{15}$ By contrast, the existence of an individual right to vote, under EU Law, for citizens of the EU in European elections has

\footnotetext{
10 Art. 1 of the Act concerning the election of the representatives of the Assembly by direct universal suffrage.

11 Art. 1(2) of the Council Decision of 25 June 2002 and 23 September 2002 amending the Act concerning the election of the representatives of the European Parliament by direct universal suffrage, annexed to Decision 76/787/ECSC, EEC, Euratom.

12 Court of Justice, judgment of 6 October 2015, case C-65o/13, Delvigne.

13 Para. 52.

14 See Annex II to the Treaty on European Union and the Treaty on the Functioning of the European Union.

15 See paras. 67-71.
} 
been explicitly denied by certain national courts, notably the Supreme Court of the United Kingdom. ${ }^{16}$

It was only in Delvigne that the Court of Justice explicitly found that such a right existed under EU Law. The case was about a French national who had lost his civic rights due to his conviction for a serious crime with a 12-year prison sentence. Now a free man, Mr Delvigne went to challenge the decision of the competent administrative body to remove him from the electoral roll of the municipality where he resided. The local court referred the matter to the Court of justice. It found that the fact that Mr Delvigne had been deprived of the right to vote under national legislation was a limitation of his right to participate in the European elections implicitly guaranteed by Art. 39(2) of the Charter. However, the Court also found that this limitation 1) was provided for by law, 2) respected the essence of the right to vote referred to in Art. 39(2) of the Charter and 3) was proportionate.

Despite the fact that the Court found, in this case, that there was no violation of EU Law, which has disappointed some commentators, ${ }^{17}$ this ruling is noteworthy for the statement that Art. 39(2) of the Charter "constitutes the expression in the Charter of the right of Union citizens to vote in elections of the European Parliament", confirming J. Shaw's analysis that "we have moved from the sole site of contestation of these rights being within and across the European political institutions and the Member States to a situation where courts are likely to be increasingly involved in deliberating about the scope and nature of those rights". 18

In this finding, the Court was probably inspired by the case-law of the European Court of Human Rights on Art. 3 of the Protocol $n^{\circ} 1$ to the European Convention on Human Rights. According to this provision, "The High Contracting Parties undertake to hold free elections at reasonable intervals by secret ballot, under conditions which will ensure the free expression of the opinion of the people in the choice of the legislature". This wording seems not to result in individual rights and freedoms but solely obligations between Parties. ${ }^{19}$ In the

$16 R$ (on the application of Chester) $v$ Secretary of State for Justice \& McGeoch $(A P) v$ The Lord President of the Council and another (Scotland) [2013] UKSC 63.

17 Van Eijken, H. and Van Rossem, J. W. (2016). Prisoner Disenfranchisement and the Right to Vote in Elections to the European Parliament: Universal Suffrage Key to Unlocking Political Citizenship? European Constitutional Law Review 12 (1), pp. 114-132, 878.

18 Shaw, J. (2008). The Political Representation of Europe's Citizens: Developments. European Constitutional Law Review 4 (1), pp. 162-186, 183-184.

19 See Harris, D.J., Bates, E., O'Boyle, M., Warbrick C., and Buckley, C. (2009). Law of the European Convention on Human Rights. Oxford: Oxford University Press, p. 712, n 10. 
1970s, however, the European Commission of Human Rights began to interpret this provision as creating "certain individual rights, such as the right to vote and the right to stand for election" ${ }^{20}$ The Court adopted the same view in MathieuMohin and Clerfayt $v$ Belgium (1987), ${ }^{21}$ and consistently considers since then that this provision enshrines an individual right to free elections, under the conditions laid down in this provision.

The Court of Justice also used the text called "explanations relating to the Charter". This text was originally prepared under the authority of the Praesidium of the Convention which drafted the Charter of Fundamental Rights of the European Union. According to the third subparagraph of Art. 6(1) TEU and Art. 52(7) of the Charter, this text must be given due regard for interpreting the Charter. It is however unlikely that this reference was decisive, since the explanations only state, in a very general way, that Art. 39(2) takes over the basic principles of the electoral system in a democratic State.

It has also been considered by commentators of the ruling 22 that this interpretation may have been prompted by a semantic change brought by the Lisbon Treaty. Whereas Art. 189 EC used to state that the European Parliament consisted of representatives of the peoples of the States brought together in the Community, Art. 10(2) and 14(2) TEU now both say that the members of the European Parliament represent the citizens of the Union. This disintermediation between the citizens and the European Parliament has also been noted by Advocate-General Cruz-Villalon in his opinion on the case, ${ }^{23}$ and some authors had already interpreted this change as implying a real right to vote and to run as a candidate for the European elections. ${ }^{24}$

Be that as it may, the (objective) principle according to which the members of the European Parliament must be elected by direct universal suffrage in a free and secret ballot has been turned into a (subjective) right of EU citizens to

20 European Commission of Human Rights, decision of 10 May 1979, no. 8612/79, Alliance des Belges v. Belgium.

21 European Court of Human Rights, judgment of 2 March 1987, no. 9267/81, Mathieu-Mohin and Clerfayt v. Belgium.

22 Van Eijken, H. and Van Rossem, J. W. (2016). Prisoner Disenfranchisement and the Right to Vote in Elections to the European Parliament: Universal Suffrage Key to Unlocking Political Citizenship? European Constitutional Law Review 12 (1), pp. 114-132, 118; Coutts, S. (2017). Delvigne: A Multi-Levelled Political Citizenship. European Law Review 42, pp. $867-881,877$.

23 See para. 100 of his opinion.

24 See House of Lords Select Committee on Constitution Written Evidence, Memorandum by Professor J. Shaw, Salvesen Chair of European Institutions, University of Edinburgh (2008). 
vote in European elections. It has also been given a broad scope of application vis-à-vis Member States.

\section{The Broad Scope of Application of the Right to Participate in European Elections vis-à-vis Member States}

The scope of the right to participate in European elections as regards Member States benefits from its dual nature. As a Citizenship right, it applies to Member States even in situations were the link with EU Law is weak (III.1). As a fundamental right, it can apply regardless of any cross-border element (III.2).

\section{III.1 A Right Applicable to Member States}

According to Art. 51(1) of the Charter, its provisions are addressed to the Member States only when they are implementing European Union law. The Court has broadly interpreted this provision in the past, especially in Fransson ${ }^{25}$ in which the Court said that "since the fundamental rights guaranteed by the Charter must (...) be complied with where national legislation falls within the scope of European Union law, situations cannot exist which are covered in that way by European Union law without those fundamental rights being applicable. The applicability of European Union law entails applicability of the fundamental rights guaranteed by the Charter". However, in the same decision, the Court added that even such a broad interpretation has its limits: "where, on the other hand, a legal situation does not come within the scope of European Union law, the Court does not have jurisdiction to rule on it and any provisions of the Charter relied upon cannot, of themselves, form the basis for such jurisdiction they are applicable every time EU Law is applicable". Later judgments of the Court of Justice, for example Torralbo Marcos ${ }^{26}$ and Siragusa, ${ }^{27}$ demonstrate that the Court can be quite strict when defining the limits of the material scope of the Charter as regards the Member States.

However, when it comes to the right to participate in European elections, the Court has proven to be quite bold about the scope of the Charter. In Delvigne, the Court found the Charter applicable to the case despite the fact that the relevant French criminal legislation had clearly not been adopted in order to give effect to any specific EU provision. The situation can, mutatis mutandis, be

\footnotetext{
25 Court of Justice, judgment of 26 February 2013, case C-617/10, Åkerberg Fransson.

26 Court of Justice, judgment of 27 March 2014, case C-265/13, Torralbo Marcos.

27 Court of Justice, judgment of 6 Match 2014, case C-206/13, Siragusa.
} 
compared with the Siragusa case. ${ }^{28}$ In Siragusa, the Court refused to consider that an order requiring $\mathrm{Mr}$ Siragusa to dismantle work carried out in breach of a law protecting the cultural heritage and the landscape fell within the scope of EU Law. The Court admitted that there was a connection between such proceedings and EU Environmental Law since protecting the landscape - the aim of the national legislation in question - is an aspect of protecting the environment. Yet, the Court insisted (para 24) that "it should be borne in mind that the concept of 'implementing Union law', as referred to in Art. 51 of the Charter, requires a certain degree of connection above and beyond the matters covered being closely related or one of those matters having an indirect impact on the other". Then the Court stated that

in order to determine whether national legislation involves the implementation of EU law for the purposes of Art. $5^{1}$ of the Charter, some of the points to be determined are whether that legislation is intended to implement a provision of EU law; the nature of that legislation and whether it pursues objectives other than those covered by EU law, even if it is capable of indirectly affecting EU law; and also whether there are specific rules of EU law on the matter or capable of affecting it.

It could have therefore been argued in Delvigne that French criminal Law only indirectly affected the right to vote and to stand as a candidate in the European elections. Furthermore, as that Court notices in $\$ 29$ of Delvigne, "Art. 8 of the 1976 Act provides that, subject to the provisions of that act, the electoral procedure is to be governed in each Member State by its national provisions", which could have broken the connection with EU Law. Let us also remember that in Spain v. United Kingdom, ${ }^{29}$ the Court stated that "the definition of the persons entitled to vote and to stand as a candidate in elections to the European Parliament falls within the competence of each Member State", allowing them to grant that right to certain persons who have close links to them, other than their own nationals or citizens of the Union resident in their territory. Yet, in Delvigne, the Court decided that the case fell within the scope of the Charter and, therefore, under its jurisdiction.

This solution, I believe, reveals the ambiguous nature of EU citizens' rights as fundamental rights. The doctrine of fundamental rights in EC Law was developed by the Court of Justice in the 7os, following pressure by several

28 Siragusa, cit.
$29 \quad$ Spain $U K$, cit., para. 78. 
national constitutional courts (especially German and Italian), to protect individuals' rights against the institutions of the (then) European Communities. These rights address mainly the institutions. Therefore, in the EU legal system, fundamental rights only apply to the States when they are acting as "agents" of the European Union. The Charter does not primarily address the Member States, it only binds them in an incidental manner - even though the Court adopted a broad view of the applicability of the Charter to the States in the Fransson judgment. As regards the Member States, the EU standards of Human Rights are functional, not federal.

This is not, and this has never been, the way EU citizens' rights operate. Since the Maastricht Treaty, they have been intentionally designed to be enjoyed by EU citizens in their relations with the Member States. Member States are therefore the primary addressees of the EU citizens' rights, whether they are laid down in the Treaties or in the Charter. This is true for all of them, even the right to vote and to stand as a candidate at elections to the European Parliament, since these elections are organised by the Member States. This right, and all the other rights of the EU citizens, have been designed primarily to impose specific obligations on the Member States as regards these EU citizens.

It is worth mentioning that this reasoning does not apply to all the citizens' rights in the EU Charter. The Title v of the EU Charter, "Citizens' rights", is quite misleading - at least in the English language. ${ }^{30}$ It gives the impression that it contains only EU citizens' rights (i.e. rights reserved for EU citizens) whereas in fact it contains rights related to citizenship as a broad concept, i.e. rights of action for individuals and legal persons in their relation with the European Union. It does contain EU citizens' rights, reserved for EU citizens and primarily addressed to the Member States. These rights are the right to vote and to stand as a candidate in elections to the European Parliament (Art. 39); the right to vote and to stand as a candidate in municipal elections (Art. 40); the freedom of movement and of residence (Art. 45) and the right to diplomatic and consular protection (Art. 46). However, it also contains rights enjoyed not only by EU citizens but more broadly by every individual or legal person, sometimes on the condition that they reside or have a registered office in a Member State. These rights are the right to good administration (Art. 41); the right of access to documents (Art. 42); the right to refer to the European Ombudsman cases of maladministration (Art. 43) and the right to petition the European

30 In French for example, this Title is called "Citizenship" ("Citoyenneté"), which is probably less misleading. 
Parliament (Art. 44). Unlike EU citizens' rights, these "non-EU-citizens-only rights" are explicitly addressed either to all the institutions, bodies, offices and agencies of the Union or to one of them (the European Ombudsman - Art. 43; the European Parliament - Art. 44). We could therefore say that in fact, these "non-EU-citizens-only rights" are less likely than any other right in the Charter to apply to Member States. The Court of Justice clearly said for example in Cicala ${ }^{31}$ and $Y S$ and $M$. and $S .{ }^{32}$ that the right to good administration protected under Art. 41 could not be used as such against a Member State - even though it also said in $M . M .^{33}$ (see especially the ambiguous wording of para 84 , "that provision is of general application") and more clearly in $H . N .^{34}$ that this article reflects a general principle of EU Law, which applies to Member States within the scope of EU Law. It is also hard to imagine how the right of access to documents of the Union, the right to refer to the European Ombudsman cases of maladministration or the right to petition the European Parliament could apply to Member States, except if somehow a national authority were to interfere with one of these rights being exercised.

Since it is in their essential nature to be applicable primarily to the Member States, it is not surprising that the fundamental rights of the Citizens are more easily applicable to Member States than the other fundamental rights protected under EU Law. From a technical point of view, this broad applicability is facilitated by the fact that the rights of the Citizens in the Charter mirror provisions contained in other sources of EU Law. For example, in Delvigne, the Court demonstrated the link between the situation in question and EU Law by saying that the French legislation must be considered as an implementation of Art. 14(3) of the TEU ("The members of the European Parliament shall be elected for a term of five years by direct universal suffrage in a free and secret ballot") and Art. 1(3) of the 1976 Act concerning the election of the members of the European Parliament by direct universal suffrage ("Elections shall be by direct universal suffrage and shall be free and secret"). In short, the Court used the EU provisions which are the material source of the relevant provision of the Charter to declare the Charter applicable, making the limitation of the scope of application of the Charter to the Member States laid down in Art. 51(1) de facto almost irrelevant for these specific rights.

31 Court of Justice, judgment of 21 December 2011, case C-482/10, Cicala, para. 28.

32 Court of Justice, judgment of 17 July 2014, joined cases C-141/12 and C-372/12, YS and M. and S., para. 67 .

33 Court of Justice, judgment of 22 November 2012, case C--277/11, M. M.

34 Court of Justice, judgment of 8 May 2014, case C--6o4/12, H. N., paras. 49 and 5 o. 


\section{III.2 A Right Applicable in Purely Internal Situations}

EU citizens' rights (understood senso strictu as the rights enjoyed only, under EU Law, by the citizens of the European Union) usually require a "cross-border" situation in order to apply. The freedom of movement and of residence applies only, in principle, to EU citizens who have crossed or want to cross an internal border of the European Union. The diplomatic and consular protection only applies to EU citizens in their relations with Member States other than those of which they are nationals. The right to vote and to stand as a candidate at municipal elections is, in fact, a specific expression of the right to national treatment. Therefore, it only applies to non-national EU citizens. ${ }^{35}$ The same applies, in theory, to the right to vote and to stand as a candidate at European elections.

In Spain v. United Kingdom, ${ }^{36}$ the Court stated at para 66 that Art. 19(2) EC (now Art. 22(2) TFEU), "implies that nationals of a Member State have the right to vote and to stand as a candidate in their own country". However, this seems to be, at best, a mere passing reference. Furthermore, the broader context of this statement gives further indication that the Court may not have meant exactly what it seems to have said. More precisely it said that Art. 19(2) EC, "like Article 19(1) EC relating to the right of Union citizens to vote and to stand as a candidate at municipal elections, implies that nationals of a Member State have the right to vote and to stand as a candidate in their own country and requires the Member States to accord those rights to citizens of the Union residing in their territory". 37 The use of two different verbs ("implies" / "requires") and the reference to the right to participate in municipal elections (a "mere" right to national treatment) seem to indicate that the existence of a right for Member States nationals to vote and to stand as a candidate in their own country is not a consequence of EU Law but merely a precondition for the exercise of the right to national treatment. Without such a pre-existing right to participate in European elections for nationals under national Law, the right to be treated like the nationals would make no sense. It does not necessarily mean that this right is by itself protected under EULaw.

In Eman and Sevinger, the European Court of Justice considered that a difference of treatment between nationals as regards the European elections fell within the scope of EU Law. ${ }^{38}$ The national law in question was a Dutch law

35 Court of justice, Order of 26 March 20o9, case C-535/o8, Pignataro, para. 17.

36 Spain v. United Kingdom, cit., para. 66.

37 Emphasis added.

$38 \quad$ Eman and Sevinger, cit., paras. 57 et seq. 
disenfranchising Dutch nationals residing in the Dutch overseas territory of Aruba from EU Parliamentary elections, whereas Dutch nationals residing in a non-member country could still vote and stand as a candidate in elections to the European Parliament held in the Netherlands. In this case, the Court found that the Netherlands Government had not sufficiently demonstrated that the difference in treatment observed between Netherlands nationals resident in a non-member country and those resident in the Netherlands Antilles or Aruba was objectively justified as regards the principle of equal treatment. In short, the Court found a breach of equality between Dutch nationals, with no consideration of free movement within the European Union. However, in this case, the infringed principle was not the right to vote and to stand as a candidate in European elections itself but the general principle of equality, as a general principle of EC Law. ${ }^{39}$ The Court only used the right to vote and to stand as a candidate in European elections in order to "link" the situation with EC Law, making the general principle of equality, as protected under EC Law, applicable to the case. All in all, the right to participate in European elections seemed to be reserved to mobile citizens, or at least citizens who do not enjoy the nationality of the Member State they live in.

It was not therefore before the Delvigne ruling in 2015, again, that the Court applied the right to vote and to stand as a candidate in elections itself to a purely internal situation. The main case, as mentioned before, was about a French national complaining that French legislation prevented him from participating in the European elections in France. There was no border-crossing or multinational element whatsoever.

The application of EU citizens' rights in a purely internal situation is not unprecedented. In Rottmann, ${ }^{40}$ the Court held that a Member State shall observe the principle of proportionality when deciding whether to withdraw its nationality from one of its nationals, especially when such a decision would deprive this citizen of his/her EU citizenship. In Ruiz Zambrano, ${ }^{41}$ the Court held that a Member State could not deprive an EU citizen - even one of its own nationals - of "the genuine enjoyment of the substance of the rights attaching to the status of European Union citizen". In this case, Belgium could therefore not refuse a non-EU national who had dependent minor children, who were Belgians and therefore EU citizens, a right of residence in Belgium, nor refuse to grant a work permit to that non-EU national. In doing so, Belgium would

\footnotetext{
39 See at para. 57 et seq.

40 Court of Justice, judgment of 2 March 2010, case C-135/o8, Rottmann.

41 Court of Justice, judgment of 8 March 2011, case C-135/o8, Ruiz Zambrano.
} 
have forced this non-EU national to leave the EU territory with his children, depriving them of "the genuine enjoyment of the substance" of the right to stay on the territory of any Member State.

However, these solutions are exceptional and apply only in extreme circumstances. In particular, the Court made it clear in its post-Ruiz Zambrano case-law that the Ruiz Zambrano solution could only apply exceptionally, in particular when the EU citizen whose third-country national family member is threatened with deportation is not a child. ${ }^{42}$ By contrast, it is rather striking that the right to participate in European elections can apply in a purely internal situation even where there is no extreme and particular circumstances "amounting to a de facto loss of one of the rights attaching to that status". 43

Could this reasoning apply to the other EU citizens' electoral right, the right to vote and to stand as a candidate in municipal elections? It would seem quite unlikely since, as mentioned above, this right is, in fact, a specific and rather limited ${ }^{44}$ expression of the right to national treatment with no direct universal suffrage clause, unlike Art. 39 of the Charter. However, the Ruiz Zambrano precedent could possibly open a door here. Let us imagine for example that, in a Member State, the restrictions to the right to vote and to stand as a candidate in local elections are excessive but non-discriminatory (i.e. they apply also to national citizens). In such a case, the right to national treatment is irrelevant, because the issue is not about discrimination. However, would it be possible to say, in such a case, using the Ruiz Zambrano test, that EU citizens are deprived of "the genuine enjoyment of the substance" of the right to vote and to stand as a candidate for municipal elections? Arguably, this is a far-fetched reasoning, and in any case, it could only apply in extreme circumstances, just like the Ruiz Zambrano solution. Moreover, in most cases, restrictions of the right to vote and to stand as a candidate would not only apply to municipal elections but to all elections - including the European elections. The situation could therefore be dealt with using the Delvigne precedent, without any need for a Ruiz Zambrano-like reasoning. However, in the (rather unlikely) case of

42 Court of Justice, judgment of 8 May 2018, case C-82/16, K.A. and others v. Belgische Staat.

43 Lenaerts, K. and Gutiérrez-Fons, J. A. (2017). Epilogue on EU Citizenship: Hopes and Fears. In: Kochenov, ed., EUCitizenship and Federalism. The Role of Rights. Cambridge: Cambridge University Press, p. 766.

44 Exceptions to the right of national treatment are laid down in several provisions of the Council Directive 94/80/EC of 19 December 1994 laying down detailed arrangements for the exercise of the right to vote and to stand as a candidate in municipal elections by citizens of the Union residing in a Member State of which they are not nationals, notably Arts. 5(3) and 5(4). 
a restriction to local elections that would not apply to European elections, a Ruiz Zambrano-like reasoning could give more substance to the political status of the EU citizens, giving them not only a right to political inclusion in other Member States (limited to local and European elections) but also a minimum right to political participation in other Member States.

\section{The Right to Participate in European Elections, a Potential Disruptor of the Distribution of Powers between the European Union and Member States}

The disruption caused by the right to participate in European elections in the distribution of powers between the European Union and the Member States results from its existence and also from its legal potential, as could be developed by the Court of Justice in future cases.

\section{IV.1 A New Citizenship Right?}

According to Art. 25(2) TFEU, only the Council, acting unanimously in accordance with a special legislative procedure and after obtaining the consent of the European Parliament, may adopt provisions to strengthen or to add to the rights listed in Article $20(2) \mathrm{TFEU}$, subject to the approval by the Member States in accordance with their respective constitutional requirements. Incorporating new citizenship rights by means of judicial interpretation "would be in clear violation of Article $25 \mathrm{TFEU}$ ". 45 In doing so, the Court would therefore not only encroach on the horizontal allocation of powers between EU institutions, trespassing the remit of the Council, but also on the vertical allocation of powers between the European Union and the Member States, who are to approve such an addition according to their respective constitutional requirements. Yet, it is clear that, in Delvigne, the Court created a new right, and that this right is reserved, under EU Law, to Union citizens. ${ }^{46}$

It could be considered that this right was implicitly protected in Art. 20(2), b) TFEU and, therefore, also in Art. 22(2) TFEU. If it was the case, the right to participate in European elections, as enshrined in Art. 20(2), b) and 22(2) TFEU, would therefore have always contained not only a right to national treatment but also an active, enforceable right to participate in European elections, unlike the right to participate in municipal elections, contains. However, this does not

\footnotetext{
45 Lenaerts K. and Gutiérrez-Fons J. A. (2017). Epilogue on EU Citizenship: Hopes and Fears, op. cit., p. 780.

$46 \quad$ See Delvigne para. 44.
} 
sit well with the finding of the Court in Eman and Sevigner ${ }^{47}$ and Spain $v U K^{48}$ that Art. 19(2) of the Treaty on the European Communities (EC), currently Art. $22(2) \mathrm{TFEU}$, was confined to applying the principle of non-discrimination on grounds of nationality to that right to vote and stand for election.

Can we consider Delvigne to be an overruling of Eman and Sevigner and Spain $v U K$ ? Such an overruling could be justified by new legal circumstances that occurred since these previous rulings, namely the entry into force of the Charter of Fundamental Rights of the European Union. One could argue that, by linking together, in the same article of the Charter, the right to national treatment and the requirement for direct universal suffrage in a free and secret ballot, the Member States of the European Union, as sovereign Masters of the Treaties, have implicitly amended the content of the former Art. 19(2) of the Treaty on the European Communities (now Art. 22(2) TFEU). In this respect, one must remember that, according to Art. 52(2) Charter, "rights recognised by this Charter for which provision is made in the Treaties shall be exercised under the conditions and within the limits defined by those Treaties". If we consider that this provision "links" the substance of the provisions of the Charter which have their source in the treaties with the provisions that they mirror, the incorporation of a new substance in a right laid down in the Charter may also affect the substance of the equivalent right in the treaties. In this interpretation, the Court has not created a new right in 2015. Instead, the Member States have implicitly amended the content of Art. 19(2) EC in 2009.

This is, however, a very far-fetched and acrobatic interpretation. It is difficult to construe Art. 52(2) Charter as a "two-way" interpretation link. Instead, it seems more plausible that the drafters of the Charter meant this provision as a "one-way" interpretation guideline, in order to prevent the substance of the Charter from going beyond the substance of the provisions of the treaties "cloned" in the Charter. One could argue that Art. 52(2) was designed precisely to prevent rulings like Delvigne. In any case, it requires a lot of legal imagination to consider that the Court has not tempered with the powers of the Member States by declaring the existence of an active, enforceable right to participate in European elections on the top of the existing right to national treatment as regards European elections.

Another possibility is that the right to participate in European elections already existed somewhere else in EU Law other than in Art. 20(2) TFEU. Art.

47 Court of Justice, judgment of 12 September 2016, case C-300/04, Eman and Sevigner, para. 53 .

48 Court of Justice, judgment of 12 September 2016, case C-145/05, Spain v. United Kingdom, para. 66. 
$20(2)$ does not list all the rights of EU citizens, as evidenced by the terms "inter alia" and also by the fact that one of the rights of EU citizens, the collective right to invite the Commission to submit a proposal for a legal act (the so-called "citizens' initiative"), ${ }^{49}$ is not mentioned in Art. $20(2)$. The right to participate in European elections could therefore be a new right added in Art. 39(2) of the Charter. However, since Art. 39(2) mirrors Art. 14(3) TEU and Art. 1(3) of the 1976 Act, and since the Court explicitly says that Article 39(2) of the Charter "constitutes the expression in the Charter of the right of Union citizens to vote in elections to the European Parliament in accordance with Article 14(3) $T E U$ and Article 1(3) of the 1976 Act", 50 it could be argued that the EU citizens' right to participate in European elections is and always was located in these provisions. This interpretation would mean that the Court has not created a new right and therefore has not encroached upon the powers of the other institutions or of the Member States under Art. 25(2) TFEU. However, even though this interpretation is much less far-fetched than the previous one, it is still quite formalistic. It assumes that the Court has merely discovered a right that was always there, even though it is unlikely that this was the intention of the drafters of the treaties and, before that, of the 1976 Act. Furthermore, it is not perfectly consistent with Spain $v U K$ and Eman and Sevinger, in which the Court did not interpret the 1976 Act in such a way.

Whichever interpretation we choose, it is therefore hard to construe the finding of the Court as not trespassing on the powers of the Council, the European Parliament and the Member States.

\section{IV.2 A Potential Minimum EU Standard for National Election Law}

By recognizing a real and enforceable right to vote in the European elections, Delvigne may have paved the way for the Court of Justice of the European Union to have a greater control over limitations of civic rights imposed on Union citizens - as long as these limitations also affect their right to participate in the European elections. Furthermore, the Court of Justice will probably, on the basis of the requirement that the elections be "free and secret", be able to fully assess whether the Member States meet fundamental democratic standards, as laid down in the case-law of the European Court on Human rights, when organising the European elections - just as the European Court on $\mathrm{Hu}-$ man Rights did itself in Matthews $v$ United Kingdom. ${ }^{51}$ Since a lot of domestic

49 Art. 11(4) TEU.

50 Delvigne, cit., para. 44.

51 European Court of Human Rights, judgment of 18 February 1999, no. 24833/94, Matthews v. United Kingdom. 
rules which apply to the European elections also apply to the other domestic elections, the Court could therefore assess large portions of the electoral legislation of the Member States. The Court's assessment could include, not only the reasonableness of the restrictions of the right to vote based on criminal conviction (as was the case in Delvigne), but also on other grounds, like mental health, ${ }^{52}$ and more broadly, the quality of the electoral regime, like the clarity of the electoral legislation, ${ }^{53}$ the existence of an effective remedy for those who claim that they have been unlawfully deprived of their vote ${ }^{54}$ or the rules governing the access to the media and the neutrality of State-owned media. ${ }^{55}$ Even though the Court does not mention it explicitly in Delvigne, it would be surprising if its review did not encompass, not only the right to vote, but also the right to run as a candidate in European elections, even though it must be kept in mind that the European Court of Human Rights "accepts that stricter requirements may be imposed on the eligibility to stand for election to parliament, as distinguished from voting eligibility". ${ }^{6}$

It is true that the more recent case-law of the Court of Justice does not really show any willingness from the Court to go further in reviewing national election law. In particular, the order issued by the President of the General Court on the $1^{\text {st }}$ July 2019 is a bit disappointing in this respect. ${ }^{57}$ In this case, the Catalan politicians Carles Puigdemont and Antoni Comín got elected in the European Parliamentary elections of 26 May 2019. However, they did not appear in person before the Spanish Central Electoral Commission to swear allegiance to the Spanish Constitution, as required by the Spanish legislation. Because of that, the Commission did not include their names in the list which was notified to the European Parliament on 17 June 2019. According to Article 12 of the 1976 Act, for the purposes of verifying the credentials of its members, the Parliament is to take note of the results declared officially by the Member States. Therefore, the President of the European Parliament sent a letter to the applicants stating that their names were not on the list of elected members

$5^{2}$ European Court of Human Rights, judgment of 20 May 2010, no. 38832/o6, Alajos Kiss v. Hungary.

53 European Court of Human Rights, judgment of 2 March 2010, no. 78039/o1, Grosaru v. Romania.

54 Grosaruv. Romania, cit.

55 European Court of Human Rights, judgment of 19 June 2012, no. 29400/o5, Communist Party of Russia and others v. Russia.

56 European Court of Human Rights, judgment of 19 October 2004, no. 17707/02, Melnitchenko v. Ukraine, para. 57 .

57 General Court, order of the $1^{\text {st }}$ July 2019, case T-388/19 R, Carles Puigdemont i Casamajó and Antoni Comin i Oliveres v. European Parliament. 
officially communicated to the European Parliament by the Spanish authorities. Consequently, and until further notice by the Spanish authorities, they cannot be treated as future Members of the European Parliament. Carles Puigdemont and Antoni Comín lodged an application before the General Court seeking, in essence, annulment of several decisions of the European Parliament which they claim prevent the applicants from taking their seats in the European Parliament as elected members. They also brought an application for interim measures. It is this second application that was dismissed by the president of the General Court in the order, based on a literal interpretation of the 1976 Act, and not taking into account whether or not the Spanish legal requirement to appear in person before the Commission was compatible with the Union Citizens' right to vote and to be elected at the European Parliament. However disappointing, this order is not the end of the story because a) the General Court still has to rule on the substance of the case in the main proceedings, b) there is a possibility of appeal against the order of the General Court before the Court of Justice and c) a legal action against the requirement to swear allegiance to the Spanish constitution is pending before Spanish courts, which may request for a preliminary ruling from the Court of Justice on the compatibility of Spanish electoral law with EU Law. ${ }^{58}$

If the Court can indeed decide on minimum standards applicable to national election laws (and this evolution has yet to be confirmed by the Court), this would affect the division of competences between the European Union and the Member States as regards electoral rules. So far, the definition of electoral rules and standards falls mostly within the remit of Member States, with the exception of the minimal requirements imposed by EU secondary law regarding European elections. However, if the Court can indeed develop a body of case-law-based standards, this body could constitute the core of an incipient electoral regime common to all the Member States of the European Union.

Another question that could arise is whether the right to participate in European elections is an exclusive right of EU citizens. In Eman and Sevinger, the Court stated in para 74 that "while citizenship of the Union is destined to be the fundamental status of nationals of the Member States, enabling those who find themselves in the same situation to receive the same treatment in law irrespective of their nationality, subject to such exceptions as are expressly provided for (...), that statement does not necessarily mean that the rights recognised

$5^{8}$ Van Elsuwege, P. (2019). Empty Seats in the European Parliament: What About EU Citizenship? VerfassungsBlog, available at https://verfassungsblog.de/empty-seats-intheeuropean-parliament-what-about-eu-citizenship/. 
by the Treaty are limited to citizens of the Union".59 This statement seems to explain the non-exclusive nature of citizenship rights by the fact that they are essentially rights to national treatment. The same conclusion can be drawn from para 76, in which the Court says that "while [Article 19(2) EC, now Art. 22(2) TFEU] (...) requires the Member States to accord those rights to citizens of the Union residing in their territory, it does not follow that a Member State in a position such as that of the United Kingdom is prevented from granting the right to vote and to stand for election to certain persons who have a close link with it without however being nationals of that State or another Member State".60 The Court then went on to find that a Member State (in this case, the United Kingdom) could legally allow non-EU Citizens (in this case, Commonwealth citizens) to participate in the European elections. It seems that the Court found that since the right to participate in the European elections was a "mere" right to national treatment, it was not exclusively reserved for EU citizens as long as it benefitted at least to them. However, if there is indeed an active right to participate in European elections, can it be inferred that this right is an exclusive right, aimed at creating a political European community? It is hard to tell, and it would be a considerable overturn of the previous case-law, but if such was the case, this limitation would encroach the power normally reserved to Member States to determine the limits of their political franchise.

On a positive note, this could, to a certain extent, respond to the criticism that the fragmented electoral rights regime across the EU results in an uneven access to the franchise. ${ }^{61}$ It could also create a minimum level playing field applicable to both manifestations of democracy in the European Union multilevel system. According to Art. 10(2) TFEU, "Citizens are directly represented at Union level in the European Parliament" whereas "Member States are represented in the European Council by their Heads of State or Government and in the Council by their governments, themselves democratically accountable either to their national Parliaments, or to their citizens". Setting some minimum standards applicable to both European elections and national elections ensures a common fundamental grammar for these two "branches" of European democracy, under the common supervision of the Court of Justice.

It is also consistent with the fact that being a functional democracy is a condition for being a Member State of the European Union, under the so-called "Copenhagen criteria". It is now well known, in particular as regards the "rule

59 Emphasis added.

6o Emphasis added.

61 Fabbrini, F. The Political Side of EU Citizenship in the Context of EU Federalism, op. cit., p. 279 . 
of law backsliding"62 in several Member States, ${ }^{63}$ that the European Union is remarkably firm on candidate States complying with the standards of liberal democracy and the rule of law, while lacking the means to enforce these very same standards vis-à-vis Member States. Reviewing whether national legislations meet the basic standards of democracy may contribute to the resorption of this so-called "Copenhagen dilemma", ${ }^{64}$ especially when illiberal governments meddle with electoral law in order to remain in power. As an example, the Court could review the various infringements to the 'one person, one vote' principle in Hungary, as well as the differences of treatment between different categories of citizens abroad depending on whether they are more or less likely to vote for the Prime Minister's ruling party Fidesz. ${ }^{65}$

It is however likely that the standards discovered and enforced by the Court, as well as the intensity of its review on Member States' electoral systems, will be limited, due to the obligation of the European Union to respect the national identities of the Member States, under Art. 4(2) TEU. The concept of national identity, coined by the Maastricht Treaty and made more (but far from completely) precise by the Lisbon Treaty, includes each country's fundamental political and constitutional structures, for example the status of the State as a Republic. ${ }^{66}$ It may therefore also include the electoral legislation, as it is strongly connected with each country's fundamental constitutional and political choices. Tension is therefore likely to arise between, on the one hand, the necessity to ensure the effectiveness of European representative democracy, which according to Art. 10(1) TFEU founds the functioning of the Union, and

62 Pech, L. and Scheppele K. L. (2017). Illiberalism Within: Rule of Law Backsliding in the EU. Cambridge Yearbook of European Legal Studies 19, pp. 3-47. See also the concept of "constitutional capture" coined by J.-W. Müller about Hungary: Müller, J.-W. (2015). Should the EU Protect Democracy and the Rule of Law inside Member States? European Law Journal 21 (1), pp. 141-16o, 142.

63 Poland, in particular, is currently the object of both a political procedure under Art. $7(1)$ TEU and infringement proceedings before the Court of Justice due to various measures undertook by the current Polish Government with the apparent aim of curtailing the independence of the judiciary. On the $12^{\text {th }}$ September 2018, the European Parliament has also activated the Art. 7(1) procedure against Hungary.

64 As far as we can tell, this expression was coined by then Commissioner V. Reding during a debate at the European Parliament concerning the situation in Romania on the $12^{\text {th }}$ September 2012: http://www.europarl.europa.eu/sides/getDoc.do?pubRef=-// EP//TEXT+CRE+2O120912+ITEM-o11+DOC+XML+Vo//EN.

65 Majtényi, B., Nagy, A., and Kállai, P. (2018). "Only Fidesz" - Minority Electoral Law in Hungary. VerfassungsBlog, available at https://verfassungsblog.de/onlyfidesz-electorallaw-in-hungary/.

66 Court of Justice, judgment of 22 December 2010, case C--208/o9, Sayn-Wittgenstein, para. 92 . 
of Union citizens' participation to the election of the European co-legislature and, on the other hand, the sovereignty of Member States. This could be, for example, an argument against the exclusive nature of the right to participate in European elections (i.e. the thesis according to which this right should be reserved to EU citizens), at least in countries where the extension of suffrage to non-EU citizens is a part of their constitutional identity. This is probably the case with the United Kingdom, since the Court stated in Spain $v$ UK that it is "for reasons connected to its constitutional traditions" 67 that the United Kingdom chose to grant the right to vote and to stand for election to Commonwealth citizens.

One must also consider the fact that the Court can only review and decide on standards applicable to national election laws insofar as the laws in question are applicable to European elections. A Member State could perfectly develop electoral rules that are strictly specific to the European elections. These specific rules are likely to be limited, because it is not in the interest of the States to create complications in their electoral regimes. However, a State can for example decide that citizens have to be of a certain age to run as a candidate for European elections, and for European elections only. If the Court was to find this age excessive for example, this finding would not apply to other national elections. Member States could even be tempted to develop a body of law specific to the European elections in order to make sure that the review exercised by the Court, along with the standards it could develop, do not "contaminate" the rest of national electoral law. However, such a strategy would be likely to create major inconsistencies. Can we really imagine that a State would agree, for example, that persons with mental difficulties would be allowed to vote for the European elections but disenfranchised for every other election?

Certain questions in particular are likely to remain either beyond the reach of the Court or subject to self-restraint. This is typically the case of national rules concerning the disenfranchisement of nationals residing in other countries, notwithstanding the position of certain authors who consider these rules incompatible with EU citizens' free movement rights. ${ }^{68}$ There are two possibilities here. First, it may be that the nationals of a Member State imposing such disenfranchisement rules reside in another Member State. In this case, the citizens in question might still be able to participate in the European elections in the host State, which means that even if their right to participate in elections

67 Para. 79.

68 See Kochenov, D. (2009). Free Movement and Participation in the Parliamentary Elections in the Member State of Nationality: An Ignored Link? Maastricht Journal of European and Comparative Law 16, pp. 197-223. 
in their State of nationality is compromised, their right to participate in European elections is not. Alternatively, the citizens in question may reside in a third country. Theoretically, in this case, the Court could review the national rules in question, since in this case the citizens are effectively barred from the possibility to participate in European elections. However, it is likely that the Court would apply self-restraint in this case, for several reasons. First, EU secondary legislation explicitly protects national discretion on this matter. ${ }^{69}$ Even though technically the right to participate in European elections prevails on secondary law, being enshrined in primary Law, this might deter the Court from going against the explicit will of the EU legislature. Secondly, even the European Court of Human Rights applies self-restraint on this question, as evidenced by its Shindler ruling concerning the 15-year rule in the United Kingdom. ${ }^{70}$ Surely, the Court of Justice is not bound by the interpretation of the European Court of Human Rights. It could be argued that the right to participate in European elections must be interpreted in its constitutional context, and notably in the light of the importance of representative democracy in the European Union as expressed in Art. 10(1) TFEU ("The functioning of the Union shall be founded on representative democracy"). However, on this issue, the national identity clause, mentioned above, could play a role in the EU context similar to the national margin of appreciation in the case-law of the European Court of Human Rights. One cannot completely rule out, however, the Court of Justice taking such a bold stance, should the question arise before it.

\section{Conclusion}

Political rights are an essential aspect of citizenship. Yet, when it comes to EU citizenship, the main focus is usually on transnational (horizontal) rights, like free movement and equal treatment, rather than on political (vertical) rights. However, after a period of "expansion" of citizens' transnational rights, during which the Court of Justice seemed to drift away from the "single-market-based"

69 Art. 1(2) of the Directive 93/109/EC of 6 December 1993 laying down detailed arrangements for the exercise of the right to vote and stand as a candidate in elections to the European Parliament for citizens of the Union residing in a Member State of which they are not nationals: "Nothing in this Directive shall affect each Member State's provisions concerning the right to vote or to stand as a candidate of its nationals who reside outside its electoral territory".

70 European Court of Human Rights, judgment of 7 May 2013, no. 19840/og, Shindlerv. United Kingdom. 
citizenship, the Court, in recent cases like Dano ${ }^{71}$ and Alimanovic, ${ }^{72}$ seems to have taken a more restrictive stance, in particular as regards the access of EU citizens to social benefits in the host Member State. ${ }^{73}$ Could it be that, at the same time, political rights have taken an opposite trajectory and have been reinforced by the Court? The case-law on political rights is too scarce to draw such a definitive conclusion. However, it is striking that the Court has adopted a bold view in Delvigne by discovering in the Charter an enforceable right for EU citizens to participate in European elections. The Court did not go as far as some would have hoped since it did not find any violation of EU Law in the case at stake. However, as some commentators have observed, it is a "classical strategy for landmark decisions" to show "restraint with regard to the outcome of the case" while scoring "an important point as a matter of legal principle". 74 Recognising an enforceable right to participate in European elections, applicable to national law regardless of its connection with EU Law and of any crossborder element has a real potential to rock the boat. In particular, I have argued that, merely by its existence, this judicially-recognised right encroaches on the power, reserved by the Treaties to Member States (inter alia), to recognise new citizenship rights. Furthermore, this right could potentially expand into a series of basic democratic standards, applicable to national election rules insofar as they also apply to European elections, with the Court of Justice having the power to review whether national election rules comply with these standards. This potential still needs to be realised, and may be hindered by the Member States' claim to sovereignty. This is however an interesting development, that deserves to be observed closely. Given the strong recognition of the democratic foundation of the European Union in the Lisbon Treaty, and despite the consistently low turnout at the European elections, political rights could develop into another strong pillar for EU Citizenship, alongside transnational / freemovement rights.

71 Court of Justice, judgment of 11 November 2014, case C-333/13, Dano.

72 Court of Justice, judgment of 15 September 2015, case C-67/14, Alimanovic.

73 This phenomenon is one of the subjects of Kochenov, D., ed. (2017). EU Citizenship and Federalism. The Role of Rights. Cambridge: Cambridge University Press. See also Thym, D., ed. (2017). Questioning EU Citizenship. Judges and the Limits of Free Movement and Solidarity in the EU. Camden: Hart Publishing.

74 Van Eijken, H. and Van Rossem, J. W. (2016). Prisoner Disenfranchisement and the Right to Vote in Elections to the European Parliament: Universal Suffrage Key to Unlocking Political Citizenship? cit., p. 130. 